\title{
ON THE SCYPHOMEDUSAE NAUSITHOË ATLANTICA BROCH AND NAUSITHOË GLOBIFERA BROCH
}

\author{
By F. S. Russell, F.R.S. \\ The Plymouth Laboratory \\ (Plate I and Text-figs. I-6)
}

Broch (I9I3) described two new species of the coronate scyphomedusa Nausithoë from the North Atlantic, N. atlantica and N. globifera. Bigelow (I928, p. 498) was inclined to think that these two species might finally prove to represent extreme variants of the one species $N$. rubra Vanhöffen, though a much larger series of specimens in a better state of preservation would be needed to give a definite decision. Kramp (I947, p. 46) considered that $N$. globifera at any rate was a good species.

I have recently seen four specimens, two of which agreed with Broch's description of $N$. atlantica and two with that of $N$. globifera. Examination of these medusae leaves no doubt about the correctness of Broch's identification. These specimens were collected in a $2 \mathrm{~m}$ stramin ring trawl by R.V. Sarsia, the two $N$. atlantica ( 35 and $25 \mathrm{~mm}$ in diameter) at $47^{\circ} \mathrm{I} 2^{\prime} \mathrm{N} ., 7^{\circ} 40^{\prime} \mathrm{W}$. on 2I July I955 with $45^{\circ}$ fathoms of wire out, and the two $N$. globifera (22 and I I $\mathrm{mm}$ in diameter) at $46^{\circ} 49^{\prime} \mathrm{N} ., 5^{\circ} 44^{\prime} \mathrm{W}$. on 6 September I955 with 500 fathoms of wire out (vertical haul).

The two species were at once distinguishable both by their shape and coloration, and a closer examination showed other differences.

\section{Nausithoë atlantica}

The largest specimen of $N$. atlantica recorded by Broch was $28 \mathrm{~mm}$ in diameter; my largest specimen is about $35 \mathrm{~mm}$ in diameter, the diameter at the coronal groove being I9 $\mathrm{mm}$ (Text-fig. I; Pl. I). In this specimen three of the gonads are the same shape as drawn by Broch (I9I3, pl. I, fig. 2), but five of them have reached a further degree of development not yet recorded. The central part of each gonad is extended towards the umbrella margin so as to be between the septa and ending only a short distance from the base of the marginal tentacle (Text-fig. 2). The only other respect in which my specimens differ from Broch's description is that the pedalia are all about the same length. Broch stated (and his pl. I, fig. I, shows) that the rhopalar pedalia were shorter than the tentacular pedalia. In my specimens all pedalia are 
approximately equal in length; if anything the rhopalar pedalia are slightly the longer, and this is rather to be expected because the distance between the coronal groove and the rhopalium is longer than that between the coronal groove and the base of the marginal tentacle.

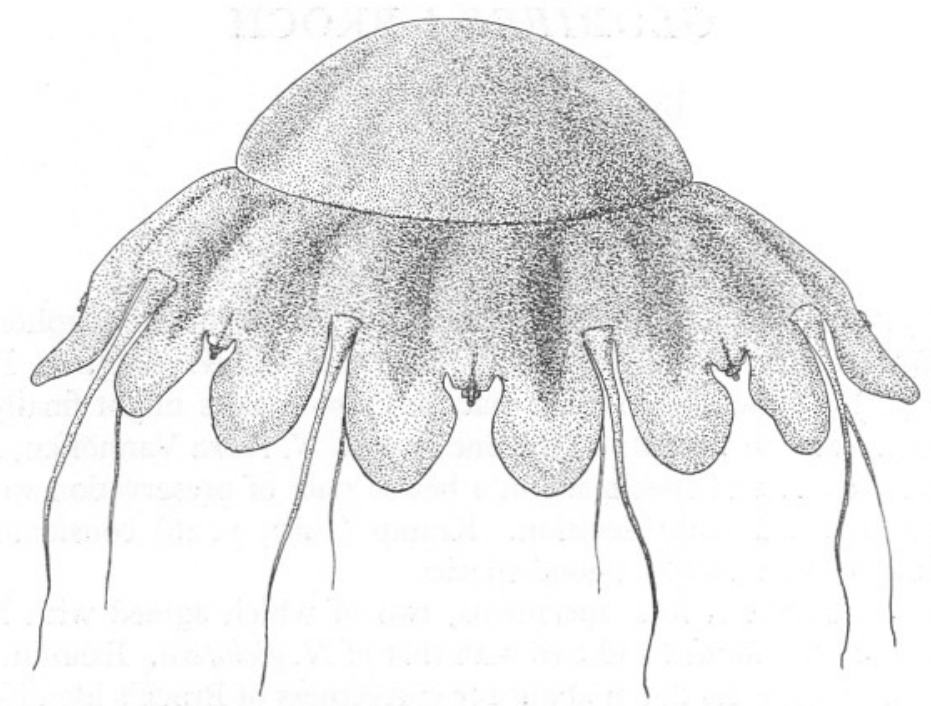

Text-fig. I. N. atlantica. Adult medusa, $35 \mathrm{~mm}$ in diameter.

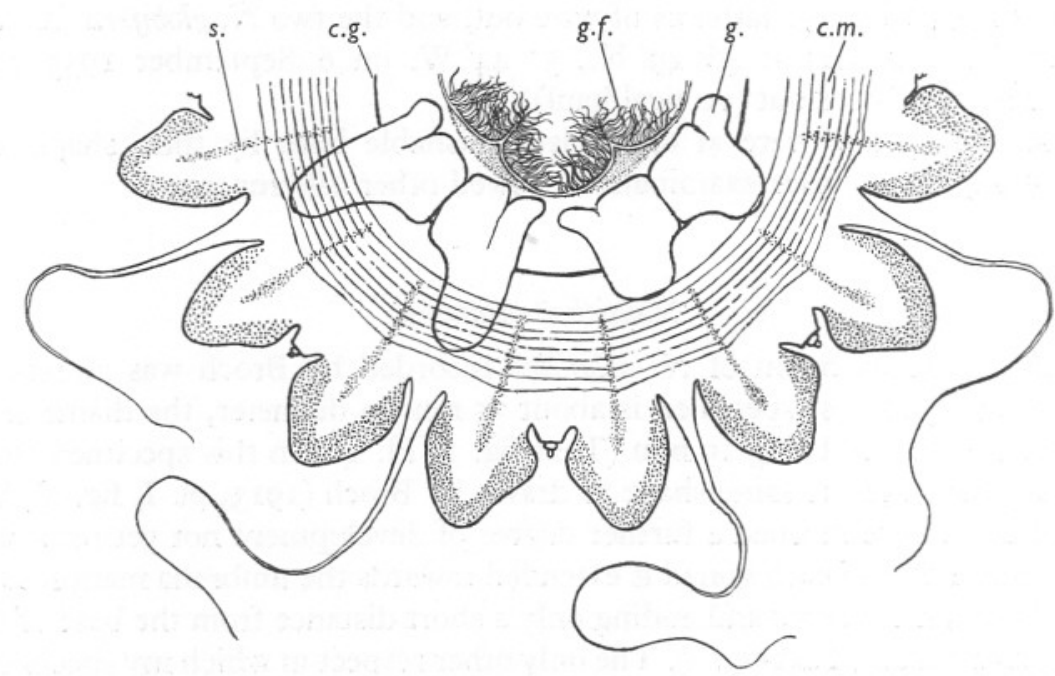

Text-fig. 2. N. atlantica. Semi-diagrammatic view of subumbrella with buccal walls of stomach cut away. The stippled areas indicate regions of fusion of upper and lower endoderm surfaces. c.g., coronal groove; c.m., coronal muscle; g., gonad; g.f., gastric filaments; s., septum. 


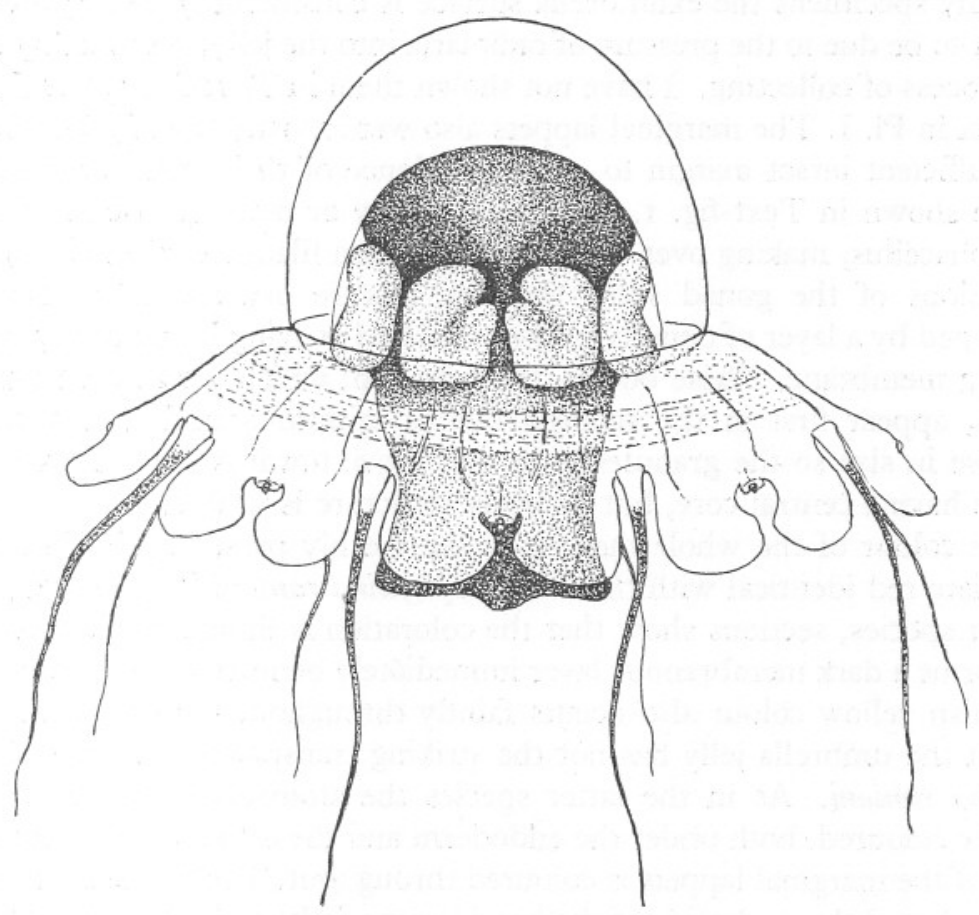

Text-fig. 3. N. globifera. Adult medusa, $22 \mathrm{~mm}$ in diameter.

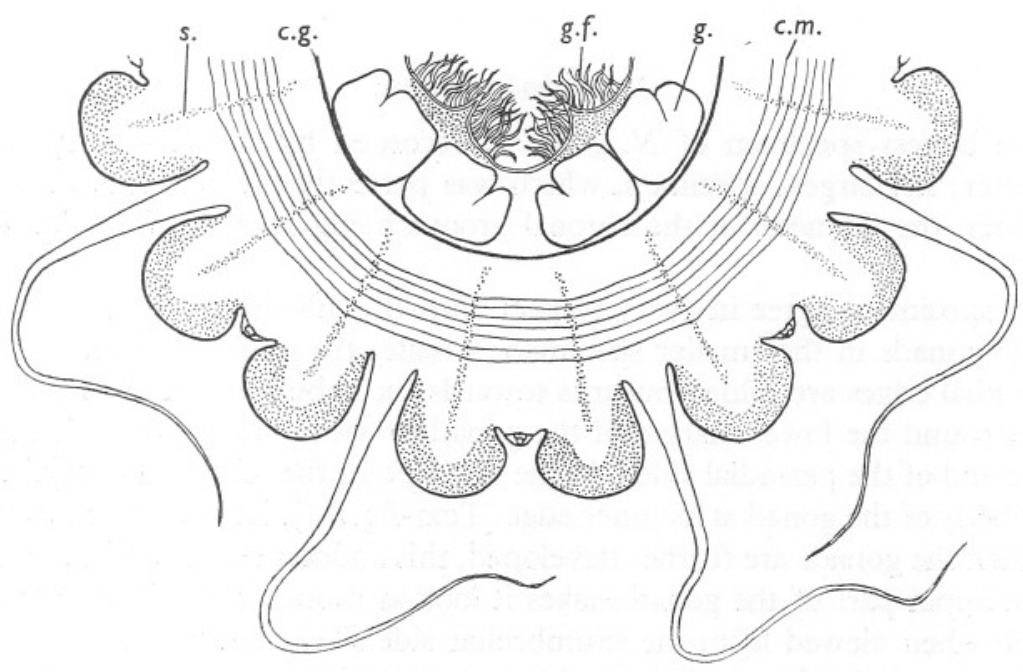

Text-fig. 4. N. globifera. Semi-diagrammatic view of subumbrella with buccal walls of stomach cut away. Details as in Text-fig. 2. 
In my specimens the exumbrella surface is considerably pitted; these pits appear to be due to the pressure of radiolaria into the jelly, presumably during the process of collecting. I have not shown them in Text-fig. I, but they can be seen in Pl. I. The marginal lappets also were mostly frayed, though there was sufficient intact margin to supply evidence of their true outlines which I have shown in Text-fig. I. There are twenty or more gastric filaments on each phacellus, making over I60 in all, and each filament arises singly.

Sections of the gonad show that the mature ova are each completely enveloped by a layer of densely packed oval bodies lying immediately beneath the egg membrane. These bodies, the largest of which are about I2-I $4 \mu$ in length, appear first in the smallest ova as minute granules. As the ova increase in size so the granules grow and move towards the periphery. The bodies have a central core, but no other structure is visible.

The colour of the whole medusa, when freshly preserved in formalin, is chocolate red identical with that of Paraphyllina ransoni (Russell, 1956). As in that species, sections show that the coloration is limited to the mesogloea and forms a dark membranous layer immediately beneath the endoderm. The brownish yellow colour also occurs faintly throughout the whole mesogloea so that the umbrella jelly has not the striking transparency of that of Paraphyllina ransoni. As in the latter species the stomach walls are especially densely coloured, both under the endoderm and the ectoderm, and the mesogloea of the marginal lappets is coloured throughout. The whole rhopalium is coloured, and the underside of the hood is especially dark (Text-fig. 5). After storage in formalin and sea water for several months the whole medusa becomes much more transparent and dark amber in colour.

\section{Nausithoë globifera}

The largest specimen of $N$. globifera recorded by Broch was $17 \mathrm{~mm}$ in diameter; my largest specimen, which was perfectly preserved, is $22 \mathrm{~mm}$ in diameter, the diameter at the coronal groove being Io mm (Text-fig. 3 and Pl. I).

My specimens agree in every respect with Broch's description.

The gonads in the smaller specimen, a male, are shield-shaped, and their interradial edges are folded inwards towards the subumbrella. This fold continues round the lower margin of the gonad to within about one-third of the upper end of the perradial side. At the latter point the fold ends and joins the main body of the gonad at its inner edge (Text-fig. $6 d$ ). In the larger specimen, in which the gonads are further developed, this sudden reduction in the width of the upper part of the gonad makes it look as though there is a protruding thumb when viewed from the exumbrellar side (Text-fig. 3).

The gonads in the smaller specimen were white except for fine flecks of pigment, and they showed in striking contrast against the dark colour of the 


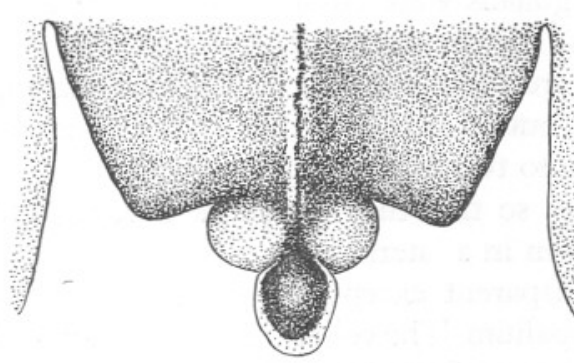

a

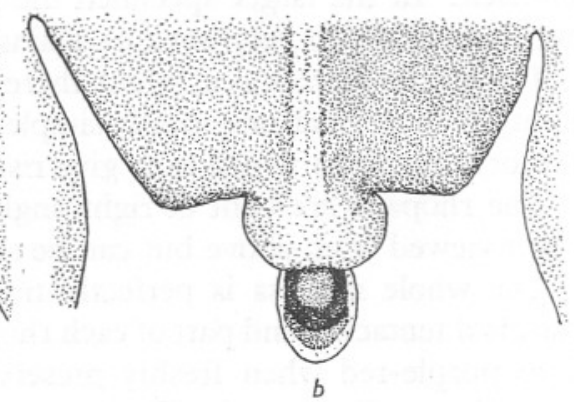

b

Text-fig. 5. N. atlantica. $a, b$, exumbrellar and subumbrellar views respectively of rhopalium.

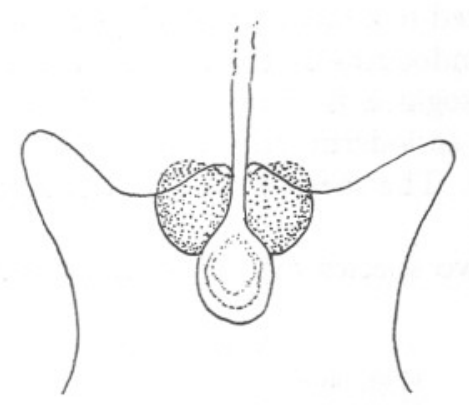

a

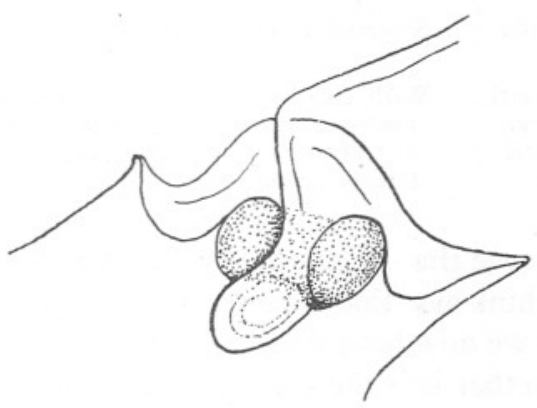

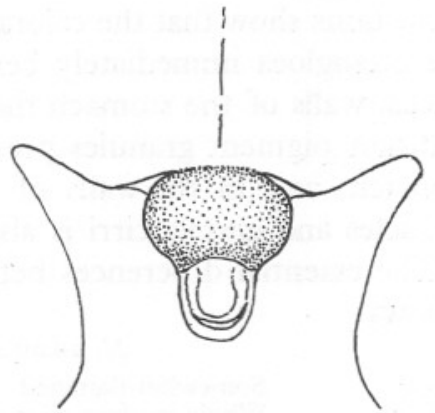

b

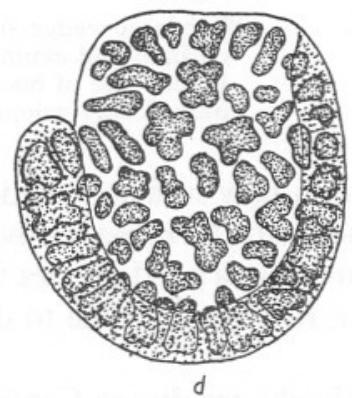

Text-fig. 6. N. globifera. $a-c$, exumbrellar, subumbrellar, and lateral oblique views respectively of rhopalium; $d$, male gonad of specimen, I I $\mathrm{mm}$ in diameter seen from subumbrellar side. 
stomach. In the larger specimen the gonads were coloured reddish brown, but they were still very obvious against the dark stomach wall.

The gastric filaments, of which there are about ten in each phacellus, making eighty or more in all, are mostly simple, but on any one phacellus there may be two or three roots which each give rise to two to four filaments.

The rhopalia are bent at right angles so that they are hidden from sight when viewed from above but can be seen in a lateral view.

The whole medusa is perfectly transparent except for the stomach, the marginal tentacles, and part of each rhopalium. The colour of the stomach was deep purple-red when freshly preserved in formalin and sea water, being darkest over the summit. The colour of the marginal tentacles was a more orange red; a short portion at the base of each tentacle was uncoloured. Only the ventral bulb of the rhopalium was coloured and this only faintly (Text-fig. 6).

Sections show that the coloration is limited to a membranous layer lying in the mesogloea immediately beneath the endoderm of the stomach. In the buccal walls of the stomach the whole mesogloea is coloured. There are in addition pigment granules present in the endoderm cells lining the whole stomach, and in the walls of the gonads. The mesogloea of the marginal tentacles and gastric cirri is also coloured.

The essential differences between the two species may be summarized as follows:

\begin{tabular}{|c|c|c|}
\hline & N. atlantica & N. globifera \\
\hline $\begin{array}{l}\text { Shape } \\
\text { Colour }\end{array}$ & $\begin{array}{l}\text { Somewhat flattened } \\
\text { Whole medusa chocolate red; } \\
\text { coloration in mesogloea only }\end{array}$ & $\begin{array}{l}\text { High domed } \\
\text { Umbrella transparent; stomach deep } \\
\text { purple red and marginal tentacles } \\
\text { orange red; coloration in both meso- } \\
\text { gloea and endoderm cells }\end{array}$ \\
\hline Gastric cirri & $\begin{array}{l}\text { About } 160 \text { in number, generally } \\
\text { single }\end{array}$ & $\begin{array}{l}\text { About } 80 \text { in number, several } \\
\text { compound }\end{array}$ \\
\hline Gonads & $\begin{array}{l}\text { Situated mainly in marginal disc } \\
\text { region }\end{array}$ & Situated above coronal groove \\
\hline Rhopalia & $\begin{array}{l}\text { With large wedge-shaped flat basal } \\
\text { cushion and exumbrella carina. } \\
\text { Under side of hood and ventral } \\
\text { bulb deeply coloured }\end{array}$ & $\begin{array}{l}\text { With small high wedge-shaped basal } \\
\text { cushion and exumbrella carina bent } \\
\text { at right angles. Ventral bulb only } \\
\text { faintly coloured }\end{array}$ \\
\hline
\end{tabular}

There is now sufficient evidence to prove that $N$. globifera Broch cannot be identified with $N$. rubra Vanhöffen. I think also that $N$. atlantica Broch must be regarded as a good species for which we now have an adequate description, and that it is not possible to decide whether it is the same as N. rubra.

My thanks are due to Captain C. A. Hoodless and the crew of R.V. Sarsia who collected the specimens; to Dr D. P. Wilson for the upper photographs in $\mathrm{Pl}$. I; to Dr J. S. Alexandrowicz for the preparations and photographs in the lower half of Pl. I; and to Miss M. L. Weir for the preparation of sections. 


\section{SUMMARY}

Specimens of the coronate scyphomedusae Nausithoë atlantica Broch and N. globifera Broch were caught in deep water off the mouth of the English Channel in July and September 1955 respectively.

These were well preserved and there is now no doubt that these are two distinct species.

\section{REFERENCES}

Bigelow, Henry B., 1928. Scyphomedusae from the Arcturus Oceanographic Expedition. Zoologica, N.Y., Vol. 8, No. 10, pp. 495-523.

Broch, HJalmar, I9I3. Scyphomedusae from the Michael Sars North Atlantic DeepSea Expedition I9I0. Rep. 'Sars' N. Atl. Deep Sea Exped., Vol. 3, Pt. I, pp. I-20. (Reprinted 1933.)

Kramp, P. L., I947. Medusae. Part III. Trachylina and Scyphozoa, with zoogeographical remarks on all the medusae of the Northern Atlantic. Dan. IngolfExped., Vol. 5 (I4), pp. I-66.

Russell, F. S., I956. On a new scyphomedusa, Paraphyllina ransoni n.sp. F. mar. biol. Ass. U.K., Vol. 35, pp. I05-IO.

\section{POSTCRIPT}

Since the above account was written I have seen three more specimens of $N$. atlantica and seventeen of $N$. globifera. These were from samples collected in the $2 \mathrm{~m}$. ring trawl, the details being as follows:

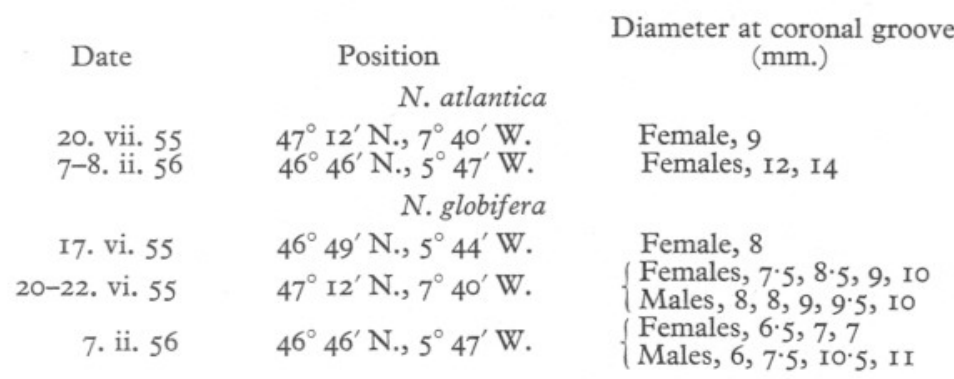

The only additional information obtained by examination of these specimens was:

$N$. atlantica: all the gonads may extend nearly to the bases of the marginal tentacles.

N. globifera: the thumb-like process is not so apparent in the female gonads as in the male gonads. Sections of the female gonads show bodies in the ova similar to those described above for $N$. atlantica.

In both species the mature eggs are white; and in both species the marginal tentacles are laterally compressed except close to the basal bulb, possibly an effect of preservation. 


\section{EXPLANATION OF PLATE I}

Left: Nausithoë atlantica Broch.

Right: N. globifera Broch.

Above: exumbrellar and lateral views of freshly preserved specimens, $X I \cdot 7$.

Below: sectors of umbrella bleached by Mayer's chlorine method, stained with borax carmine and mounted.

N.B. In the upper photographs of N. atlantica the gonads can be seen in places showing through the jelly. The white objects present on the dome of the umbrella are radiolarians which have become pressed into the jelly. 

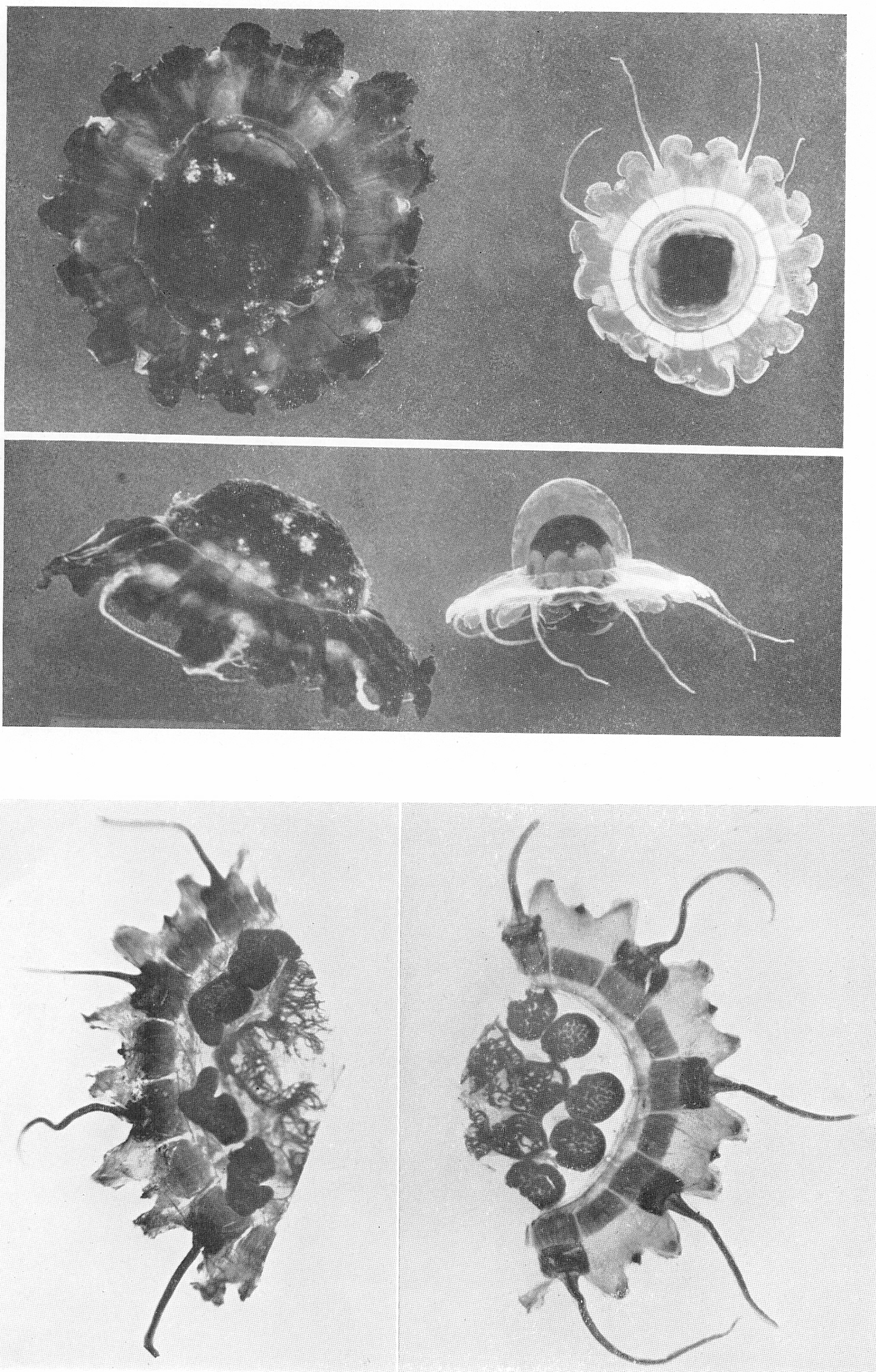

(Facing p. 370) 